\title{
Corporate Social Responsibility and Web Reporting
}

\section{Emil Knezović}

International University of Sarajevo

\section{Dr. Senad Bušatlić}

International University of Sarajevo

\section{Senadin Plojović}

University of Novi Sad

\begin{abstract}
Corporate Social Responsibility (CSR) represents the obligation of an individual, or in this case the company, to be beneficial to the society. The concept will no longer consider profit maximization of a company but to take care of the society and the environment in which they operate. In simple words, Corporate Social Responsibility is the way of doing business by combining economic benefit with sustainability of the environment. This paper puts special emphasis on the importance of Corporate Social Responsibility reporting and on the role of companies' websites in it. This is the main reason why we analyzed the websites of the companies in Bosnia and Herzegovina with the specific focus on the CSR content.
\end{abstract}

Keywords: Corporate Social Responsibility, Corporate Strategy, Reporting, Website.

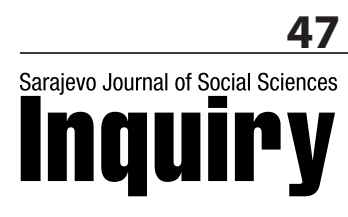




\section{INTRODUCTION}

The economic crisis and stagnation in economic development of Bosnia and Herzegovina (BH) has been an ongoing issue since 2009 and this is supported by the most of the macroeconomic indicators such as unemployment, trade and GDP. (BHAS, 2015) The real answer to this situation, whether due to ignorance, incompetence or political orientation, has not been provided by the governing structures. This crisis affected the economy and has caused the stagnation of the companies that should be the ones that "hustle" the economic development of the country. Therefore, research teams should be directed towards finding the competitive models that companies could use in the market in order to perform better and to gain competitive advantage over their rivals, especially the foreign ones.

Business ethics, today, are an indispensable part of business practice and as such they represent the precondition for business success in both the short and long term (Aleksic, 2007). As a part of business ethics, Corporate Social Responsibility (CSR) represents, according to Durovic \& Randic (2011), activities that have the impact on the environment, society and human resources. With CSR, companies are trying to maximize their positive impact on society and to minimize the bad one. As such CSR becomes very important to consumers all over the world. Implementing CSR has become the must for businesses all over the world. The general social belief is that companies are the ones who created environmental and social problems by their tenure of people and nature through the centuries. This is the reason why they are perceived as those who are responsible for solving these issues. Francois-Marie Arouet known as Voltaire (1832) was a writer who was the first one to use a well-known phrase "with great power comes great responsibility". Later on, many artists, politicians and others used this phrase in their speeches and it became a norm for responsibility. In the modern economy, companies have a lot of power so they should be responsible toward the society in which they operate.

Today, business is very dynamic and simple implementation of CSR is no longer sufficient. Besides, it is almost "mandatory" for the companies to report on CSR in the proper way. Business reporting is not focused on financial reporting, but according to Jackosn, Boswell \& Davis (2011:55) there is a shift "toward additional 
sustainability reporting". The defied reports help companies to measure the outcomes/consequences (direct or indirect) of their actions, set goals and manage change. (Kumar, 2014) Companies are trying to use CSR in order to improve their business opportunities. Corporate Social Responsibility has become the tool for attracting and retaining customers, employees, partners and investors since being socially responsible increases the trust others have toward the organization. The role of the World Wide Web, as the Internet tool, is very important in the promotion of all activities that the company is doing. In his book, Charlesworh (2009) states that the quality of the website, in the form of text or presentation published on it, may contribute to achieving online credibility which is in today's "intangible world" the main drive for potential buyers in their process of evaluating companies. (Miljkovic, Alcakovic \& Alcakovic, 2011)

Through this paper, we emphasize the importance of CSR to the enterprises. Further, we analyze companies in Bosnia and Herzegovina and their usage of websites' potential for the purpose of promoting their CSR activities.

\section{LITERATURE REVIEW}

\subsection{Defining the Corporate Social Responsibility}

Even if the concept of CSR is the modern one, it started to form the real shape several decades ago. Some initial literature and papers that included parts of this concept are dated from an earlier period. Barnard (1938) defined this concept as the analysis of five aspects of the environment: economic, legal, moral, social and physical.

According to Carroll (1983), profitability and obedience to the law are foremost conditions when discussing the firm's ethics and the extent to which it supports the society, in which it exists, with contributions of money, time and talent. He assumes that corporate responsibility goes far beyond the pure profit and that therefore it should take into the consideration other aspects, especially the social ones.

Inquipy

2015/2 


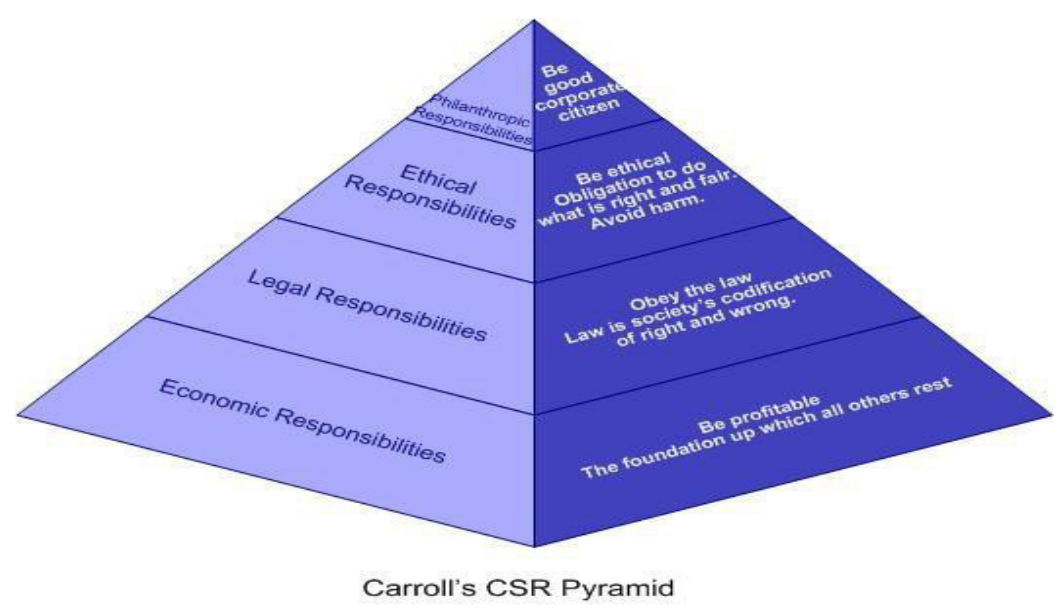

Figure 1: Carroll's CSR Pyramid

Source: Research Methodology, 2012

Since the companies perceive CSR as a diversification tool, they engage in many different areas by which they try to obtain more gains. Carroll (1979) argued that companies have to look outside of their core responsibilities (economic and legal).

In one of his later works, he added two more responsibilities that each of the companies has to take into consideration. (Carroll, 1991) Based on that, today's concept of Corporate Social Responsibilities is constructed out of four main areas of responsibilities:

1. Economic area - Throughout the history, the main responsibility for each company was to maximize the profit. This meant that they had to reach their financial goals. Such responsibility represents the most important responsibility of the company. Everything is dependent on the "profit process" (produce and sell). In order to be able to fulfill any other responsibility, this one has to be satisfied, otherwise companies face serious problems.

2. Legal area - Economic responsibilities have to be reached in accordance to the law and regulations of the society in which the company operates. Those companies that gain economic benefits by obeying the laws are perceived as socially responsible. It further impact perception of customers since they believe that such companies use quality materials and production processes that pass minimum legal requirements and that their final goods are safe and will not harm the environment. 
3. Ethical area - Those companies who are believed to be ethical are expected to do the right things for the society. In simple words, societal expectation is that reaching the financial goals should be done in the "right way". General belief is that companies should avoid the actions that are against society norms even if they are not forbidden by law. If we take an example of less developed countries that have no strict laws about environmental protection, it is still not good harm environment just because "someone" is not forbidding it.

4. Philanthropic area - This area of responsibility represents the one where investments are made in the society in which the company operates. Philanthropic responsibility gives big credibility to the company. Society expects from successful companies to invest the money in the projects that bring benefits to both of them. Most investments are done in educational and scholarship programs, cultural programs, renovation of certain institutions, green fields, parks, sport centers, clubs and others. Based on everything mentioned above, it may be stated that there are two forces that drive social responsibility: companies and society.

Because it includes corporate citizenship, corporate sustainability, business ethics, shareholders management, environmental management, and corporate social performance, Visser (2005) defined CSR as an umbrella concept. According to Waldman (2006), the company that practices CSR is the one that invests in employees' development and empowerment. It is the company that shares information with its employees in order to give them better knowledge, so they could progress at their work.

Guthey, Langer, \& Morsing, (2006) called CSR as the latest management fad, which refers to the fact that this concept should be developed even more in the future.

\subsection{Concept of CSR}

There are several perspectives from which people, organizations and governments look at CSR. According to Marrewijk (2003), there are three basic approaches to the CSR that were developed through the time.

Shareholder approach refers to the one that is based on 
economic reasons. Main idea behind this approach is to maximize the profit and to prong benefits to those who "own" the company. The center of this approach is the company and its future. Those who manage should focus on the well-being of the company, to strength it and to find the way for improvement and expansion.

Stakeholder approach refers to the approach that includes certain other parts of the company that are also important. This approach does not see its owners as the only ones that are important, but also puts importance on other stakeholders such as employees, customers, partners and others. It is taught that actions of the company do not affect only the company, but also other entities that are connected to it.

Societal approach refers to the widest approach of all. It puts importance of company's responsibility toward the society, because without society's approval the company could not operate. This "modern" approach shows that company is the fundamental part of society and because of that they should support and invest in it.

\subsection{CSR - Benefits \& Costs}

In modern societies, companies stand responsible for their actions in the highest degree than ever. Modern media, especially the digital one, are covering almost all actions in the world and each wrong step may reduce companies' sales and profits. There is a general belief that companies which practices CSR can improve their overall business performances. Benefits that may be gained from this concept are many, but in the following part they are categorized in five groups. On the other hand, there are opponents to this approach which state that the company would not do it without a "hidden Inquiry motive". (Friedman, 1970; Davis, 1973; Militaru \& Ionescu, 2006; $2015 / 2$ Broomhill, 2007; Nurn \& Tan, 2010; Hejase et al., 2012; SinoGerman Corporate Social Responsibility Project, 2012)

By analyzing works mentioned above, we summarized some of the most important benefits and costs that CSR bring to the companies. The summary of it is presented in the Table 1. 
Table 1: Benefits and Costs of CSR

Source: Authors' compilation

\begin{tabular}{|l|l|}
\hline Benefits & Costs \\
\hline $\begin{array}{l}\text { Public image/reputation } \\
\text { (Public belief: company with ethical } \\
\text { principles is producing products using } \\
\text { quality and standardized materials and } \\
\text { final product is not harmful for the } \\
\text { society) }\end{array}$ & $\begin{array}{l}\text { Company costs } \\
\text { (Long-term investment - no } \\
\text { immediate return; often results in } \\
\text { agency cost) }\end{array}$ \\
\cline { 1 - 1 } $\begin{array}{l}\text { Customer satisfaction } \\
\text { (Positive correlation among CSR and } \\
\text { consumer retention) }\end{array}$ & \\
\cline { 1 - 1 } $\begin{array}{l}\text { Employee satisfaction } \\
\text { (CSR results in employee motivation; } \\
\text { attracts better workforce) }\end{array}$ & Public costs \\
\cline { 2 - 2 } $\begin{array}{l}\text { Costs reduction } \\
\text { (Employee satisfaction leads to higher } \\
\text { productivity and decrease in the costs) }\end{array}$ & \\
\cline { 1 - 1 } $\begin{array}{l}\text { More business opportunities } \\
\text { (Opportunities regarding } \\
\text { environmental and societal areas) }\end{array}$ & \\
\hline
\end{tabular}

\subsection{CSR and Modern Business}

CSR, as a concept, should include the creation of create strategies with the consideration to all stakeholders involved. Companies should have long-term orientation and therefore follow the combination of the winning strategy which states that the company should give equal importance to human resources, societal balance and the environment. (Ganescu, 2010 on Lepinuex et al. (2010)) The importance of using CSR, as a strategic operation, has been highly recommended for companies in modern business. (McElhaney, 2009) In simple words, Corporate Social Responsibility is perceived as the strategy for obtaining and sustaining competitive advantage. In support for this statement, Gazzola \& Colombo (2014) state that "By integrating CSR into the corporate strategy and stakeholder management, organizations can ensure that the increasing of shareholder value doesn't overshadow the need to behave ethically to their stakeholders". According to Galbreath (2008), CSR is in accordance to the six fundamental dimensions of strategies and as such it may be incorporated by the companies. The main point here is to address that CSR may be observed as an integral part of corporate strategy that in the future may become separate a strategy governed by independent department. 


\subsection{Relationship between CSR and Business Performance}

We already mentioned the benefits that CSR may bring to the companies. It is important to highlight that this is not just a theory and because of that the following part provides support for this claim. As time passed, and the concept has been developing and started to be used, the relationship among the CSR and business performance has been changing. Previously, due to different economic regimes in the world, it was hard to find the evidence on relationship among these concepts. Even in certain cases, there was a negative relationship meaning that the money that a company invested did not give expected returns. However, with open economy and open competition, positive relationships are the ones that researches find mostly. Overton (2009) wrote the following: "even though some studies postulated a negative relationship or no relationship between the Corporate Social Responsibility (CSR) and business performance, more recent studies provided the empirical evidence that there is a positive relationship between those two constructs". In the analysis of Chinese Mineral Firms, Corporate Social Responsibility, as a variable, resulted in positive relationship with three financial indicators; return on assets (ROA), return on equity (ROE) and earnings per share (EPS). (Pan et al., 2014) Positive correlation was also confirmed in Karagiorgos (2010) study in Greece, where he found that CSR positively impacts stock returns. Long term sustainable development is not the only outcome of CSR and this was supported by the work of Kanwal et al. (2013). They found "considerable positive relationship" among CSR and financial performance. Stronger relationship among these two variables can be expected in the companies with high customer awareness. (Servaes \& Tamayo, 2013) Corporate Social Responsibility practices are also applicable in the banking industry which is demonstrated in the study of Malik \& Nadeem (2014) where CSR resulted in a positive relationship with EPS, ROA, ROE and the Net Profit.

\subsection{CSR promotion}

Even though CSR reports are, in most cases, done on voluntary basis (no law requirements, but companies are feeling the pressure of the public) companies again found the way to use the CSR reports for their own benefits. In the analyses done by Juscius, Sneideriene \& Griauslyte (2014), results showed that CSR becomes the main tool that connects different marketing activities. They also presented the framework behind 
the social responsibility reporting as shown in the Figure 2.

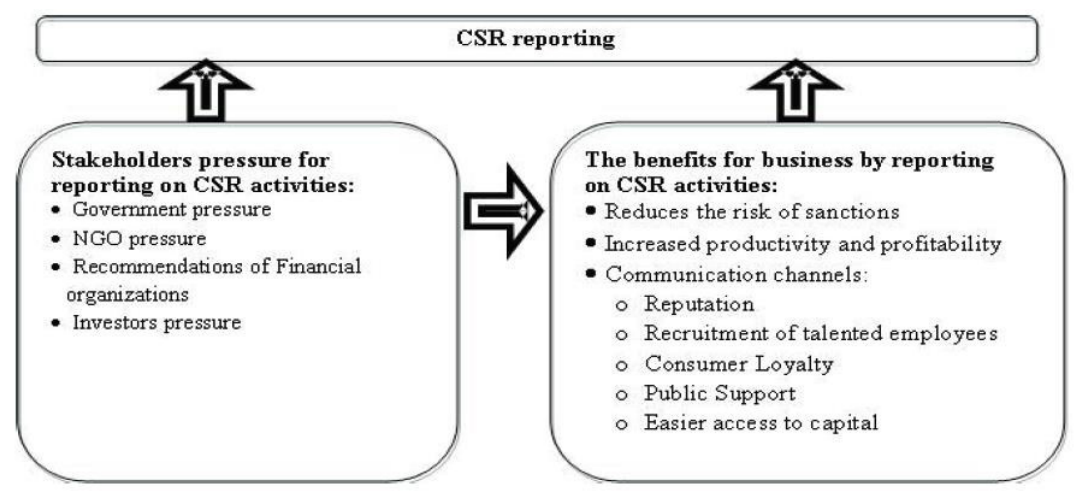

Figure 2: CSR Reporting

Source: Juscius, Sneideriene \& Griauslyte (2014)

Titles on CSR reports may differ from company to company and that is the reason why we found it under sustainability, responsibility, accountability or citizenship. However, all of them are reporting on economic, environmental and social dimensions of the companies. (Roca \& Searcy, 2012)

CSR is largely stakeholders oriented and that is the main reason why companies started to incorporate CSR reports. According to Jackson, Boswell \& Davis (2011), the driving force behind this process lies in the recognition that there are "finite resources that should be utilized by today's businesses, as well as future generations"

Although, in most cases, these reports are made on a voluntary basis, they help companies to implement systematic approach toward social responsibility and activities they made in that field by which the pool of business opportunities is improved. (Moravcikova, Stefanikova \& Rypakova, 2015) By reporting on CSR actions, companies become more recognized in society and build awareness of themselves as responsible citizens.

Benefits of making CSR public are two dimensional. In the first place, here we think about all stakeholders that require information about companies' whole business and not just the economical part. By providing such information, companies are improving their public image which in return can bring better employees, financing sources such as those in the area of sustainability and improvements in overall relationship with the stakeholders. The second dimension relates to the 
internal benefits; in a way that making those kind of reports enables managers to implement "internal learning within the firm" for its employees. (O'Rourke, 2004) Making reports enables managers to evaluate the performance of the company on the basis of investment and returns of initiatives such as CSR.

Kumar (2014) emphasize the importance of Global Reporting Initiative (GRI) which represents the leader in promoting the sustainability reports. In this way those reports represent value to the companies' values and governance model which is oriented toward the so called "sustainable global economy".

CSR reports are not just used by the external sources, but they are also valuable for the internal ones. In support of this statement, we provide one very interesting conclusion that was made by Hedberg \& Malmorg (2003) where they found that CSR report and the GRI guidelines are more beneficial for internal users because it provides the information about the activities done and results obtained.

\subsection{CSR and Role of Companies' Website}

We already explained the importance of CSR reporting and now we demonstrate why web promotion of CSR is important. Web promotion, or as some say marketing through the use of web, enables companies to attract stakeholders and increase the traffic on their website. (Javadian Dehkordi et al., 2012) Thousands of companies are promoting their products and service through the internet because, according to Van Doren, Fechner \& Green-Adelsberger (2010), it became the foundation for manybusiness today. E-commerce, where the core is a website, enables companies to facilitate new information, reach and interact with their consumers and sell their products or services. (Gangeshwer, 2013) Promotion of CSR activities through the website is almost identical to the promotion of any kind of product or service. In simple words, by promoting CSR, company promotes itself, builds a stronger relationship with the current customers and attracts new ones. For that reason, website content of the companies is a very important segment of modern business. Having this in mind, we opted for analysis of websites content of the companies regarding the area of Corporate Social Responsibility. 


\section{METHODOLOGY, DATA ANALYSIS \& RESULTS}

Analysis for this study was used based on the work of Veljkovic \& Petrovic (2011); where the authors tested did socially responsible companies in Serbia explored the promotional opportunity of a website. In that way, they tried to see how much of CSR actions were published on websites based on four main questions:

1. Does the website contain a special section dedicated to social responsibility?

2. Is social responsibility, in the broadest sense, built in the mission and/or vision of the company?

3. Whether the website contains official report (annual) on the activities and initiatives that fall within the domain of social responsibility?

4. If the website contains information about the state of CSR, what is their content in qualitative terms?

Although our analysis was based on the same questions, the nature of our study was different in several ways. The analysis in our case was done for the top 100 companies in net revenue for the year 2013 in Bosnia and Herzegovina according to Poslovne Novine (2014). In that way, we wanted to test whether the most "successful companies" explore the potential that CSR offers through web promotion.

To gain the data, we searched for all top 100 big companies and got the following results. Firstly, let us introduce the information regarding the existence of websites of big companies in Bosnia and Herzegovina. All companies that were in the list of top 100 companies are still in the business, but only 78 of them are having the website accessible. Most of these 22 do not have it and only a few of them had a website under the construction.

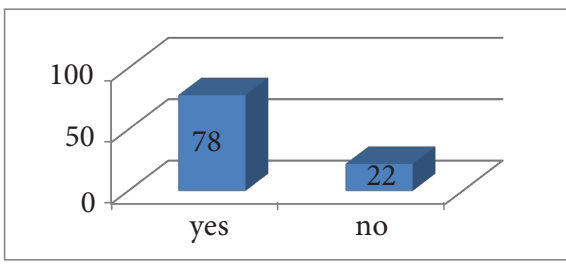

Figure 3: Top 100 big companies in BH - Existence of websites 
The figure above illustrates some concerning data. It shows that, even in time of IT and internet, our leading companies are not emphasizing their websites as a tool for better business operations.

Bearing in mind that one of the trends in the global market is Corporate Social Responsibility, its role, as one of the promotional tools, is very important. Because of that, companies in the world, in increasing numbers, devote the special section on their web sites to the activities related to CSR. The situation in Bosnia and Herzegovina is presented in the Figure 4.

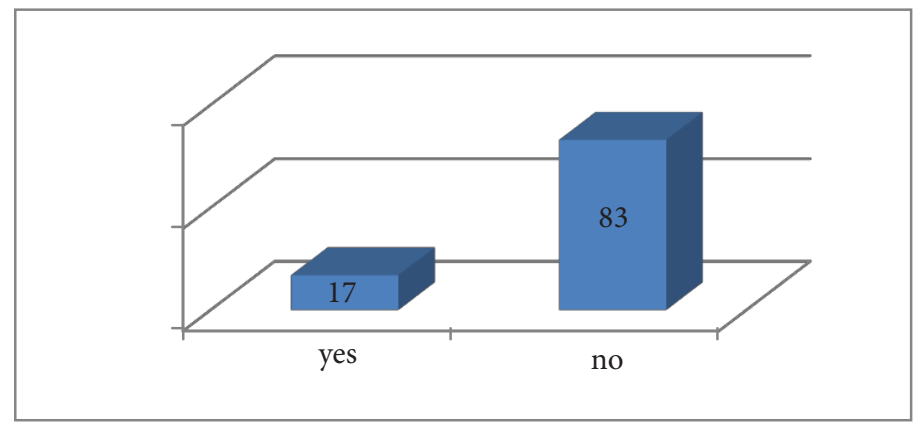

Figure 4: Top 100 big companies in $\mathrm{BH}$

Existence of CSR section on websites

Numbers that are shown in the Figure 4 are not promising, especially because this outcome comes from the analysis of big $\mathrm{BH}$ companies. We witnessed that best practices worldwide stressed importance of CSR as a business strategy, however, in practice; large companies in Bosnia and Herzegovina did not accept this concept. These large percentages of companies that do not use the promotional attractiveness that websites provide deny themselves a bigger pool of business opportunities in the future. Looking at a website, as a promotional tool, we can stress out that it serves as the first contact with potential investors and partners (especially the foreign ones). In that way, $\mathrm{BH}$ companies miss an opportunity of representing themselves: their business success, credibility and sustainability.

Company's mission statement summarizes the essence of the existence. Because of that, it represents a very important part of a website. Through the mission statement a company tries to communicate with the public about its goals for the future. One of the first things, that potential investor or partner searches about the company is its mission. Therefore, "incorporation" of the CSR into the 
mission statement of a company, contributes to higher involvement of employees toward the organizational goals and, in this case, social responsibility. The results regarding the CSR and its existence in the mission of $\mathrm{BH}$ companies are presented in the Figure 5.

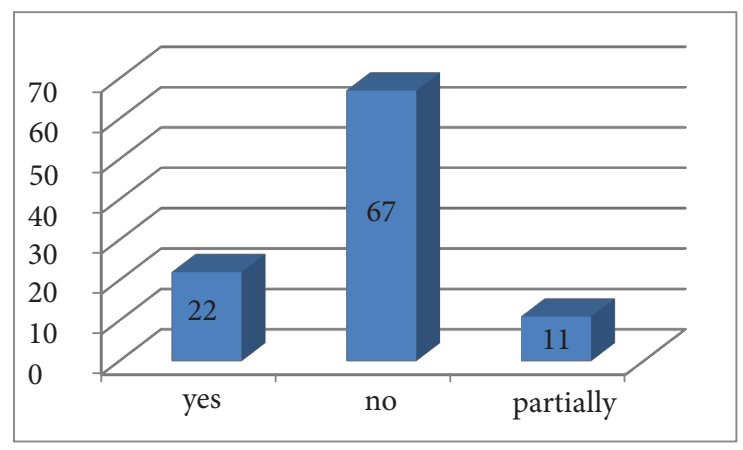

Figure 5: Top 100 big companies in $\mathrm{BH}$

Existence of CSR section on their websites

From the analysis presented in the figure above, we may state the results are discouraging. Bearing in mind that only $22 \%$ of companies incorporate CSR into their mission statement is something that has to be changed in the future. Company owners have to imagine just how many potential investors or partners have been and still are rejected by wrongly conceptualized missions and visions statements represented or not at companies websites, that would like to initiate talks about cooperation; products/services, activities, market shares and business in general. The last question that we covered in this paper was regarding the special reports that companies present to the public regarding their CSR.

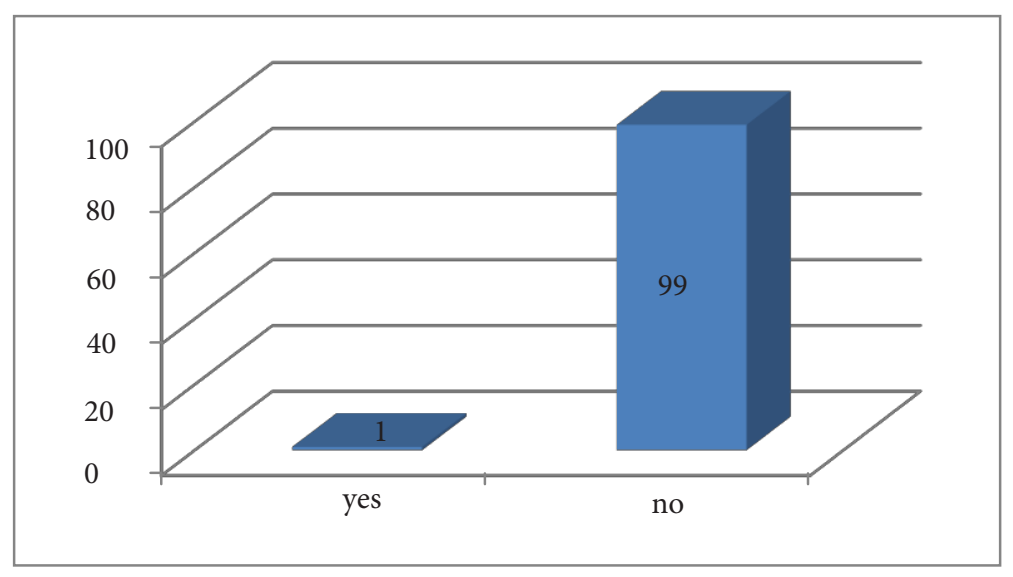

Figure 6: Top 100 big companies in $\mathrm{BH}$

Existence of CSR section on companies' websites 
The Figure 6 represents very discouraging result. Out of 100 companies, only one posted a special report regarding CSR activities. This shows the general perception of $\mathrm{BH}$ companies toward the concept of CSR and websites as their promotional tool in modern business.

\section{CONCLUSION}

The purpose of this paper was to highlight the importance of Corporate Social Responsibility for companies and to analyze the usage of company's website potential for the purpose of promoting the CSR.

Results of the analysis show that BH companies are not "aware" of opportunities and potential which are provided by the World Wide Web and their own websites and the concept of CSR reports. Therefore, we can agree that, like in any other business models which are on a voluntary basis, companies in Bosnia and Herzegovina are introduced in it slowly and for the most of the time, late. Here, we may conclude that $\mathrm{BH}$ companies' perception is that it is enough to meet the legal requirements and that the other things do not affect their image, reputation and the final decision of customers.

Observing the CSR, as a tool for achieving and sustaining the competitive advantage in the dynamic global market, we may state that this type of the market "does not forgive" mistakes and therefore it is not enough for the company to only implement CSR activities but also to present and promote them in the best possible way.

Since the new business philosophy is built exactly on the elements of CSR, for companies in Bosnia and Herzegovina would be our recommendation to embrace the CSR concept in the complete sense and to implement it in that way. If a larger part of companies has a website (78\% of them have it) it represents a cost to the company because it must pay the domain and maintenance for it. The goal for these companies should be to "turn their costs to the profit" and to adapt to the modern market requirements. Simple work on a website, introducing CSR elements into their vision, mission and objective statements, with having full CSR reports available to the public would generate more visibility and therefore more business opportunity with partners that are sure what they want. For those companies who do not use the website, the first step is definitely to introduce it and to follow the guidelines provided in this paper. 
It is also important to mention that companies in $\mathrm{BH}$ report on CSR mostly through the news and other websites. CSR sections are not arranged in the manner used by, for example, international companies. Many companies in BH would, under CSR, put their certificates as representation of their care for stakeholders. Further, most sections regarding the CSR were donations and sponsorships. Here, again companies do not report, but use the website's space for putting contact information and other irrelevant data. Based on this information, we conclude that companies are having a problem with the thorough thinking and deciding what to report in respect to CSR. This has to be changed and web space has to be used strategically in order to attract new investors and partners, make the employees more committed and in the end have positive financial records.

We conclude this paper with the words of Maguire (2011: 8) who states that CSR reporting is here to stay for the next at least several decades and therefore the companies in $\mathrm{BH}$ have to start thinking about and implementing this concept in its full capacity, and we would add, immediately.

\section{REFERENCES}

Aleksic, A. (2007). "Poslovna etika - element uspješnog poslovanja”. Zbornik Ekonomskog Fakulteta u Zagrebu, 5 (1), 419-429.

Barnard, C.I. (1938). The Functions of the Executive. Harvard University Press.

BHAS, Agency for statistics of Bosnia and Herzegovina (2014). Available from: $<$ <ttp://www.bhas.ba/>. [November, 2015].

Broomhill, R. (2007). Corporate Social Responsibility: Key Issues and Debates. In: Orchard, L. \& Matiasz, S. [eds.] Dunstan Paper Series, Don Dustan Foundation, Adelaide 1/2007.

Carroll, A. B. (1979). "A Three-dimensional conceptual model of corporate performance”. Academy of Management Review, 4 (4), 497-505.

Inquipy

2015/2

Carroll, A. B. (1983). "Corporate social responsibility: Will industry respond to cutbacks in social program funding?”. Vital Speeches of the Day, 49, 604-608.

Carroll, A. B. (1991). "The pyramid of corporate social responsibility: Toward the moral management of organizational stakeholders". Business Horizons, 34 (4), 3948.

Charlesworh, A. (2009). Internet marketing: A Practical Approach. ButterworthHeinemann. 
Davis, K. (1973). "The Case For and Against Business Assumption of Social Responsibilities”. Academy of Management Journal, 1, 312-322.

Dehkordi, J. G., Rezvani, S., Rahman, S. M., Fouladivanda, F. \& Jouya, F. S. (2012). "A Conceptual Study on E-marketing and Its Operation on Firm's Promotion and Understanding Customer's Response". International Journal of Business and Management, 7 (19), 114-124.

Durovic, I. \& Randic, D. (2011). "Značaj korporativne društvene odgovornosti za savremeno poslovanje". Paper presented at the Nacionalna konferencija o kvalitetu, Kragujevac.

Friedman, M. (1970). “The Social Responsibility of Business is to Increase its Profits". The New York Times Magazine, 13 (32-33), 122-124.

Galbreath, J. (2008). "Building corporate social responsibility into strategy". European Business Review,

21 (2), 109-127.

Ganescu, M. C. (2012). "Corporate social responsibility, a strategy to create and consolidate sustainable businesses". Theoretical and Applied Economics, 19 (11), 91-106.

Gangeshwer, D. (2013). "E-Commerce or Internet Marketing: A Business Review from Indian Context”. IJUNESST, 6 (6), 187-194.

Gazzola, P. \& Colombo, G. (2014). "CSR Integration into the Corporate Strategy”. Cross-Cultural Management Journal, 16 (2), 331-338.

Guthey, E., Langer, R., Morsing, M., (2006). Corporate social responsibility is a management fashion. So what?. In: Morsing, M. \& Beckmann, S. C. [eds.] Strategic CSR Communication, DJOF Publishing, Copenhagen, 39-60.

Hedberg, C. \& Von Malmborg, F. (2003). “The Global Reporting Initiative and corporate sustainability reporting in Swedish companies". Corporate Social Responsibility and Environmental Management, 10 (3), 153-164.

Hejase, H., Farha, C., Haddad, Z. \& Hamdar, B. (2012). "Exploring the Multiple Benefits of CSR on Organizational Performance: Case of Lebanon". Journal of Social Sciences, 1 (1), 1-23.

Jackson, A., Boswell, K. \& Davis, D. (2011). "Sustainability and Triple Bottom Line Reporting - What is it all about?". International Journal of Business, Humanities and Technology, 1 (3), 55-59.

Juscius, V. Sneideriene, A. \& Griauslyte, J. (2014). "Assessment of The Benefits of Corporate Social Responsibility Reports as One of the Marketing Tools". Regional Formation and Development Studies, 3 (11), 88-99. 
Kanwal, M., Khanam, F., Nasreen, S. \& Hameed, S. (2013). "Impact of corporate social responsibility on the firm's financial performance". IOSR Journal of Business and Management, 14 (5), 67-74.

Karagiorgos, T. (2010). “Corporate Social Responsibility and Financial Performance: An Empirical Analysis on Greek Companies”. European Research Studies, 8 (4), 85108.

Kumar, R. (2014). "A Study on Sustainability Reporting Practices in Indian and Global Companies with Special References to the Petroleum Companies". Abhinav National Monthly Refereed Journal of Research in Commerce \& Management, 3 (4), 15-25.

Lepineux, F., Rose, J. J., Bonanni, C. \& Hudson, S. (2010). La RSE. La responsabilité sociale de l'entreprises: Théories et pratiques. Dunod, Paris.

Maguire, M. (2011), The Future of Corporate Social Responsibility Reporting, Available from:

<http://www.bu.edu/pardee/files/2011/01/PardeeIIB-019-Jan-2011.pdf>.[October, 2015]

Malik, M. S. \& Nadeem, M. (2014). "Impact of corporate social responsibility on the financial performance of banks in Pakistan". International Letters of Social and Humanistic Sciences, 21, 9-19.

McElhaney, K. (2009). "A Strategic Approach to Corporate Social Responsibility". Leader to Leader, 2009 (52), 30-36.

Militaru, Gh. \& Ionescu, S. (2006). “The Competitive Advantage of Corporate Social Responsibility”. U.P.B. Sci. Bull., 68 (2), 89-103.

Miljkovic, M. Alcakovic, S. \& Alcakovic, S. (2011). “Značaj internet marketinga za poslovanje dvadeset vodećih Srpskih kompanija”. Singidunum Revizija, 8 (2), 137 144.

Moravcikova, K., Stefanikova, L. \& Rypakova, M. (2015). "CSR Reporting as an Important Tool of CSR Communication”. Procedia Economics and Finance, 26, 332338.

Nurn, C. W. \& Tan, G. (2010). “Obtaining Intangible And Tangible Benefits From Corporate SocialResponsibility”. International Review of Business Research Papers, $6(4), 360-371$.

O'Rourke, D. (2004). Opportunities and Obstacles for Corporate Social Responsibility Reporting in Developing Countries, World Bank Group.

Overton, N. (2009), "An evaluation of customer perceptions of coffee manufacturers and their CSR activities - The case of Kenco Coffee and the Rainforest Alliance". Master Thesis, De Montfort University Leicester, United Kingdom. 
Pan, X., Sha, J., Zhang, H. \& Ke. W. (2014). "Relationship between Corporate Social Responsibility and Financial Performance in the Mineral Industry: Evidence from Chinese Mineral Firms".

Sustainability, 6 (7), 4077-4101. Poslovne Novine (2014). 1251-1252. Privredna Štampa, Sarajevo, 32-35.

Roca, L. C. \& Searcy, C. (2012), Reporting on Corporate Sustainability Performance, Director notes, The Conference Board, Available from:

$<$ http://searcy.blog.ryerson.ca/files/2013/11/TCB-DN-V4N21-12.pdf>.[November, 2015].

Servaes, H. \& Tamayo, A. (2013). "The Impact of Corporate Social Responsibility on Firm Value: The Role of Customer Awareness". Management Science, 59 (5), 1045 1061.

Sino-German Corporate Social Responsibility Project (2012). Costs and Benefits of Corporate Social Responsibility (CSR): A company level analysis of three sectors: Mining industry, chemical industry and light industry. GIZ.

Van Doren, D. C., Fechner, D. L. \& Green-Adelsberger, K. (2010). "Promotional strategies on World Wide Web". Journal of Marketing Communications, 6 (1), 21-35.

Van Marrewijk, M. (2003). "Concepts and definitions of CSR and Corporate Sustainability: Between agency and communion". Journal of Business Ethics, 44 (2), 95-105.

Veljkovic, D. \& Petrovic, D. (2011). "Korporativna društvena odgovornost i značaj njene promocije”. Marketing, 41 (1), 29-42.

Visser, W. (2005). "Corporate citizenship in South Africa: a review of progress since democracy”. Journal of Corporate Citizenship, 2005 (18), 29-38.

Voltaire (Arouet, F.M.), Beuchot, A. J. Q. \& Miger, P. A. M. (1832). Oeuvres de Voltaire. 48, Lefèvre, Paris.

Waldman, D. A., Sully, M., Washburn, N. \& House, R .J. (2006). "Cultural and leadership predictions of corporate social responsibility values of top management: A Inquipy globe study of 15 countries". Journal of international Business Studies, 37 (6), 823$2015 / 2$ 837. 